\section{Twenty-five years of the AIDS epidemic in Brazil: principal epidemiological findings, 1980-2005}

\author{
Vinte e cinco anos da epidemia de AIDS no Brasil: \\ principais achados epidemiológicos, 1980-2005
}

\author{
${ }^{1}$ Instituto de Pesquisa \\ Evandro Chagas, Fundação \\ Oswaldo Cruz, Rio de Janeiro, \\ Brasil. \\ 2 Diretoria Regional de \\ Brasília, Fundação Oswaldo \\ Cruz, Brasília, Brasil. \\ 3 Instituto de Comunicação \\ e Informação Científica \\ e Tecnológica em Saúde, \\ Fundação Oswaldo Cruz, \\ Rio de Janeiro, Brasil. \\ Correspondence \\ M. G. P. Fonseca \\ Diretoria Regional de \\ Brasília, Fundação \\ Oswaldo Cruz. \\ SEPN 510, Ministério da \\ Saúde, Unidade II, $4^{\circ}$ andar, \\ sala 407, Brasília, DF \\ 70750-520, Brasil. \\ gorettifonseca@fiocruz.br
}

\section{Abstract}

The Brazilian AIDS epidemic is undergoing important changes in its third decade. The present article reviews some central findings: the proportional reduction in cases related to injection drug use; the stability, in recent years, of new cases in the male homosexual/bisexual population; and the relative and absolute increment in heterosexual transmission, even though the estimates of incident rates still point to the first two categories mentioned as those most affected by the epidemic. Still should be detached the persistent increase in incidence rates among women and its stability in the younger age groups, probably the result of behavior changes (such as the consistent use among youth of condoms in sexual relations with casual partners and a reduction in cases related to injection drug use). It is well-know that HIV prevalence in the general population has stabilized at less than $1 \%$, which characterizes Brazil as one of the countries with a concentrated epidemic. The article also emphasizes the growth of AIDS morbidity-mortality in the less favored socioeconomic strata and in women, and the stability of the mortality rate among men.

Acquired Immunodeficiency Syndrome; HIV Seroprevalence; Sexual Behavior; Temporal Distribution
Maria Goretti P. Fonseca 1,2

Francisco I. Bastos 3

\section{Introduction}

AIDS enters its third decade as an epidemic of great transcendence, affecting the quality of life of the population, principally young adults, and having a great impact on the economy and societal and family structures. It is estimated that at the beginning of the present century, worldwide, there are 40 million people living with HIV, with 4 million new infections per year, and 2.8 million deaths worldwide 1 .

Substantial changes in the levels of morbidity-mortality have been recorded, due to the introduction of highly active antiretroviral therapy (HAART), starting in 1996 2,3, with a significant increase in life expectancy in places where HAART is available, and furthermore with marked socioeconomic ${ }^{4}$ and gender differentials 5 .

The majority of people infected with HIV or AIDS in developing countries have not benefited from, as they do not yet have access to, therapies that are presently available in developed countries, presenting a profound inequality in relation to access to essential medications 6 .

This article reviews the principal epidemiological findings of the Brazilian epidemic and summarizes the results of national research through articles published in journals indexed in MEDLINE and/or SciELO databases up to 2006, as well as via complementary analyses of databases of AIDS cases reported to the Brazilian Ministry of Health (Reportable Diseases Da- 
tabase - SINAN) from 1980-2005. The present review does not cover AIDS treatment or access to health services.

\section{Composition of epidemiological findings}

With an estimated 600,000 people living with HIV 7 and 400,000 accumulated cases reported by the end of the first half of the first decade of this century 8 , the Brazilian epidemic has presented successive changes in its profile since the first reported case in 1980. It is probably more appropriate to refer to it not as a single epidemic, but rather as a mosaic of regional epidemics, reflecting the extension and socio-geographic diversity of the country, and its regional heterogeneity 9,10 .

The number of reported cases increased rapidly until 1992. At this point the growth lost its impetus, a phenomenon that continued until the end of the 1990s, at which point stabilization followed, basically due to the stabilization of incidence rates in the Southeastern Region of the country and in 20-34 year old males (the main strata affected by the national epidemic), although in older strata and in other geographic regions and among women, growth continued until the beginning of the present decade.

Like any dissemination process in heterogeneous populations, the epidemic declined progressively within certain population segments, such as those with better socioeconomic conditions 11 and those of lesser magnitude, such as injection drug users 12 , aside from segments directly benefited by the implementation of specific efficient and effective prophylactic measures, such as control of blood banks 13, and the prophylaxis of mother-to-child transmission 14 .

The decade of 1980 was characterized by a concentration of cases in the 20-49 age group, mainly due to transmissions between male homosexuals/bisexuals, roughly concurrent with a rapid increase in cases registered due to blood transfusions, principally among hemophiliacs 15 .

In the subsequent period, a progressive increase in cases among injection drug users (IDU) was observed, that, from the second half of that decade until the first half of the 1990s represented the second-most relevant category of exposure, corresponding to approximately $1 / 3$ of cases with known exposure 16, and constituting, finally, the primary category of exposure for 13-39 year old males. From that point on, a decrease in the number of cases in this category of exposure was observed 12 , with similar proportions, from that point on, to those observed between 1980 and 1990, with the exception of the Southern Region of the country where the IDU epidemic did not show signs of stabilization 12 .

From this point on, a fast increase in the number of cases due to heterosexual transmission has been observed, including a significant number of AIDS cases among women, and an important proportional growth in male cases that, in the first half of this decade corresponded to $50 \%$ of male cases with known exposure. Homosexual/bisexual transmission since the middle of the 1990s has been responsible for approximately $1 / 3$ of reported AIDS cases. Given the reduced numbers of men who have sex with other men (MSM), if compared with the heterosexual population 17, there can be no doubt that the heterosexual segment of the population has been especially affected by the epidemic, in Brazil, and in many other countries 18 .

The AIDS epidemic has experienced a marked increase in 30-39 year old adults of both sexes. In general, among men, AIDS rates have tended to stabilize, a trend that started in the second half of the last decade among men of up to 39 years old, and there has even been a reduction in men younger than 34 . On the other hand there has been a persistent increase in older age groups, with a greater incidence among heterosexual men over 40. Accentuated growth has been observed in men between 40 and 59 years of age, and especially in the 40-49 year-old age group, whose infection rates have passed those observed in 20-29 year-old males in the present decade 8 .

Women have been affected most intensely in the 25-39 year-old age group, and, differing from men, still demonstrate increasing rates of incidence in practically all age groups, with the exception of 20 to 29 year olds, among whom the incidence rates have stabilized in the present decade and have been exceeded by cases registered in women 40-49 years old 8 .

With a reduction in the incidence rates among young people in recent years, the median age of new cases among men has risen from 32 years (referring to the first half of the 1990s) to 37 years (in recent years). Cases of AIDS recorded in the homosexual/bisexual categories have presented, over time, a more stable median age, ranging during the period from 33 to 35 years. Among the IDU category, the median age observed was younger until the first half of the 1990s, with a subsequent increase from 27 to approximately 35 years. A similar variation has been noted in cases recorded in the heterosexual category with a progressive increase in the median age from 33 to 37 years during the period (1980-2005).

Female cases have been recorded in younger people, if compared to male cases, with the median age increasing from 30 years, at the begin- 
ning of the epidemic, to 35 years in recent years. Among female cases registered among IDU, a younger median age has been observed, with an increase from 26 to 33 years over the period under analysis.

The progressive spread of HIV through unprotected sexual relations, between heterosexuals, IDU, or not, has progressively transformed women into the most relevant segment of the population, in reference to the dynamics of the epidemic in Brazil. The incremental increase of female participation, in its turn, resulted in an increase in the number of children infected via vertical transmission, a trend partially reverted by the institution of vertical transmission prophylaxis, beginning with those measures implemented after Protocol ACTG 076 19. With the progressive country-wide implementation of measures established by Protocol ACTG 076, a substantial reduction in the number of pediatric AIDS cases was observed 20, principally when the trends were analyzed by year of birth 21 , corresponding, in some studies, to less than $10 \%$ of the cases anticipated, for children born from 2001 on 22. Meanwhile, because of the precariousness of access to prenatal care and its poor quality 23 , characterized by lack of HIV testing in pregnant women and/or poorer counseling, especially among the pooer 24,25 , vertical transmission continues to be a relevant problem in some parts of the country 26,27 .

\section{Spatial distribution of AIDS in Brazil}

Although the epidemic is still concentrated in the great Brazilian urban centers, mainly in large and medium-sized municipalities in the south-central part of the country, the proportional participation of these municipalities in relationship to the whole epidemic has been reduced over the years.

Until the beginning of the 1990s, $65 \%$ of Brazilian AIDS cases were reported in municipalities with more than 1 million inhabitants, a percentage that decreased to $55 \%$ by the end of the 1990 s. In a complementary manner, the proportion of cases reported in municipalities with populations of between 50,000 and 200,000 inhabitants increased with a speed inversely proportional to their populations' size. The municipalities with more than 500,000 people in the middle of the 1990s had the lowest rates of growth, with stabilizing tendencies, in comparison to those with up to 200,000 inhabitants which, until today, exhibit the biggest growth rates 15 .

Despite this evidence of a process of interiorizing, the AIDS epidemic in Brazil is a predominately urban one 15 , basically due to the heavy population concentration in Brazilian cities. There are more recent indications that the rural population has started to get caught in the epidemic's dissemination networks, evidenced by the rising incidence rates, still relatively low, among rural workers 28 .

Initially restricted to the Center-South $\mathrm{Re}$ gions 15 , the epidemic has been gradually expanding to the Northern and Northeastern Regions. The Southeastern Region is the one most affected by the epidemic, with more than half the total cases, and the highest rates of incidence until the end of the 1990s, but there has been a reduction in the speed of growth since the middle of that decade, with a clear indication of a stabilization trend in the present decade 8 .

In contrast, even in recent years, there have been observed epidemic growth trends in the other regions, especially in the Southern Region, which has shown the greatest growth rate from the end of the last decade, exceeding, since that time, the incident rates in the Southeastern Region 8 . In the first years of the epidemic the male homosexual/bisexual was the preponderant exposure category in all regions, maintaining itself in recent years in second place, particularly in the Northeastern Region where more than $40 \%$ of male cases belong to this exposure category 29 .

The accentuated growth of heterosexually transmitted cases has been observed in all regions of the country since the beginning of the 1990s. Another peculiarity of the Brazilian epidemic is the concentration of AIDS cases in injection drug users in the Center-South part of the country, principally at the end of the 1980s and the first half of the 1990s 29. In the Southern Region, until the present, this form of transmission corresponds to more than $20 \%$ of registered cases, with a very slight decline or even an increase in some municipalities 12 .

\section{Particularly vulnerable populations}

In recent years the epidemic has disseminated itself more slowly because of various factors: saturation of high-risk population segments 30 ; behavior modification in certain segments 17,31 ; implementation of preventive measures; impact of preventive programs and proper management of the clinical syndrome 30,32 , with antiretroviral (ARV) therapy, that reduces the infectiveness of people with HIV/AIDS, and, in consequence, the transmission of HIV 33. This impact has made itself felt more effectively since the first years of the present decade, starting with ARV therapy (mono and dual) at the beginning of the 1990s and, mainly, after 1996, through the introduction 
of HAART which substantially reduces the infectiousness of people living with AIDS 33 .

The Brazilian epidemic does not characterize itself, at least not at the present, as a wholly "heterosexualized" one, such as those observed in Sub-Saharan Africa 1, where an inverse gender ratio can be observed (i.e. a great number of cases are recorded among women, if compared to the recorded cases of AIDS among men), given that, in Brazil, the male homosexual/bisexual category still represents an important factor in the transmission of HIV.

When the rates of incidence until the end of the 1990s of male homosexual/bisexual exposure and IDU exposure are roughly estimated, utilizing as numerators the cases of AIDS in males from 15-49 years of age, in these categories 29 , and, as denominators, the proportions of informed MSM and males who "used injectable drugs at least once in their life" 17 , it becomes clear that the IDU were the most affected by the epidemic, with incidence rates of over 600 cases per 100,000 , or 6 per every 1000 IDU diagnosed as AIDS cases in the first half of 1990s. It can be additionally verified that the MSM population constituted the second-most affected male population with incidence rates of approximately 300 cases per 100,000 or 3 cases of AIDS per 1000 MSM until the end of the 1990s (Table 1).
Nevertheless, the data systematized on Table 1 cannot be actualized at this time due to the delay in notification to the Brazil's AIDS cases database (SINAN), verified after this period 34,35,36,37. The cases of AIDS "recovered" (not originally reported to SINAN) from the Laboratory Exams Control System of the National Network of Lymphocyte CD4/CD8 Count and Viral Load (SISCEL) or even the Brazilian Mortality Information System (SIM) do not contain information about the category of exposure 8 , which should be exacted in investigative work through searching doctors casebooks, or the development of a methodology to correct differential delays by exposure category.

It should be pointed out that the identification, in the SINAN databank, of commercial sex workers, one of the most at-risk groups in various contexts (especially in underdeveloped countries such as Thailand ${ }^{38}$, and India ${ }^{39}$ ) is not achievable. Little is known about AIDS or HIV infection in this population because of the lack of studies of representative samples of this population segment in Brazil.

Among cases of AIDS in persons with more than 13 years of age, who had mentioned sexual exposure as their presumable cause of infection, and had the nature of their sexual contact informed and classified, around $70 \%$ of male cases were said to have involved multiple partners.

Table 1

Estimated population, AIDS cases, and incidence rates (per 100,000), among individuals aged 15-49 years old, according to their exposure category, by year of diagnosis. Brazil, 1988-1998.

\begin{tabular}{|c|c|c|c|c|c|c|}
\hline \multirow[t]{2}{*}{ Year } & \multicolumn{2}{|c|}{ Population * } & \multicolumn{2}{|c|}{ AIDS cases ** } & \multicolumn{2}{|c|}{ Incidence rates } \\
\hline & MSM & IDU & MSM & IDU & MSM & IDU \\
\hline 1988 & $1,226,279$ & 640,851 & 2,132 & 769 & 173.9 & 120.0 \\
\hline 1989 & $1,250,818$ & 653,932 & 2,681 & 1,226 & 214.3 & 187.5 \\
\hline 1990 & $1,274,756$ & 666,692 & 2,833 & 2,655 & 222.2 & 398.2 \\
\hline 1991 & $1,302,287$ & 681,364 & 3,450 & 3,732 & 264.9 & 547.7 \\
\hline 1992 & $1,334,952$ & 698,303 & 4,132 & 4,407 & 309.5 & 631.1 \\
\hline 1993 & $1,340,639$ & 701,540 & 3,927 & 4,689 & 292.9 & 668.4 \\
\hline 1994 & $1,359,838$ & 711,534 & 4,120 & 4,501 & 303.0 & 632.6 \\
\hline 1995 & $1,378,376$ & 721,196 & 4,007 & 4,592 & 290.7 & 636.7 \\
\hline 1996 & $1,446,158$ & 756,118 & 4,197 & 4,787 & 290.2 & 633.1 \\
\hline 1997 & $1,470,477$ & 768,807 & 4,663 & 4,748 & 317.1 & 617.6 \\
\hline 1998 & $1,490,878$ & 779,458 & 5,211 & 4,561 & 349.5 & 585.2 \\
\hline
\end{tabular}

MSM: men who have sex with other men; IDU: injection drug users.

* Applying a proportion of 3.5\% to the population estimates for 15-49 age bracket for males according to the Instituto Brasileiro de Geografia e Estatística [IBGE; Brazilian National Institute of Geography and Statistics] and a proportion of 0.9\% for IDU to the population estimates for both sexes in the same age bracket, according to Szwarcwald et al. 17;

** Brazilian National STD/AIDS Program reported AIDS cases as of December 30, 200529 
Among female cases there was observed great diversity, with around $30 \%$ of cases among those women that referred to multiple partners, $30 \%$ with IDU partners, while less than $20 \%$ informed that their partners had multiple sexual partners and a similar proportion of female cases who had had seropositive partners without being possible to identify their risk factor for HIV infection.

The deceleration of the epidemic in recent years in regard to incidence and mortality rates 8 , are not manifested universally, but selectively in relationship to the populations most affected, reflecting complex models of dissemination and saturation, access and adherence to prevention 17 and treatment 40 initiatives, aside from the relative efficiency of transmission depending on the mixing patterns of these various population segments and their respective sexual practices 41 and/or psychoactive substance use.

\section{AIDS and social inequality}

The impact of socio-economic inequality on the spread of the AIDS epidemic in Brazil has been in evidence since the middle of the 1990s 16,42. The epidemic began in an upscale socioeconomic population 11. The male cases that pertained to the categories "homosexual" and "bisexual" were recorded predominantly among highly-educated individuals 43 . With relevant modifications over the years, by the end of the 1990 s over $50 \%$ of those cases were reported in individuals with more than 8 years of schooling, which compares with the cases among IDU, which, since the beginning of the epidemic, occurred in the great majority (80\%) among individuals with a lower level of education 43 .

Disseminating itself into different regions and into sparsely populated municipalities 44 , the epidemic has undergone a progressive change in terms of the social parameters of individuals living with AIDS, increasingly affecting the poorer strata $11,28,43$.

The phenomena of progressive transformations in the socioeconomic profiles of AIDS cases can be clearly evidenced in the dynamic observed in the Northeastern Region, where there has appeared, in the last decade or so, an epidemic that is still in a growth phase, and which exhibits high incidence rates, and proportions of cases, among individuals of a higher socioeconomic level, in contrast to the Southeastern Region, where the epidemic is older and more mature, and where the highest incidence rates and proportion of cases are being observed among the median class and lower strata 11,28.

The spread of the epidemic in Brazil follows a dynamic pattern, that, arriving at a "new" population or location, initially affects population segments with a high socioeconomic level, and then expands itself gradually to poorer segments 43,44 , obeying a pattern of dissemination initially into more extended social networks, then, later into more strongly interconnected and transversal social strata, first described by Klovdahl 45.

It must be emphasized that, on the other hand, the findings from the Southern Region have documented an important growth in all socioeconomic strata, demonstrating a pattern of HIV dissemination which is distinct from the ones observed in other parts of the country. Probable explanations include the greater IDU population as a key element of the epidemic in that region 12 .

As the years pass heterosexual transmission has become predominant in the overall epidemic dynamic, and it, in a similar manner to what occurred initially with the homosexual and bisexual segments, begins principally with the higher socioeconomic levels, then rapidly disseminates itself into the lower socioeconomic strata 28 . Among women there has been observed a significant growth that is relatively independent of socioeconomic conditions, but with a faster spread among the poor 11,28 .

With the change in the way education has been measured, from "degree of education" to "years of study", implanted in 2000 into the electronic system of disease notifications in Brazil (SINAN) 46 , a discontinuity in this variable occurred, with a high percentage of "unknown" during the first years of its application, thus compromising the analyses of social inequalities in AIDS cases, having education as a proxy of the socioeconomic status of the cases. The same problem can be observed in the SIM in regard to cause of death for whatever causes, that, starting in 1996, underwent a similar change to the way education has been measured (see http://www. datasus.gov.br).

It is important to emphasize that the dynamics of AIDS cases reflect, in truth, the process of dissemination of HIV, that can date back 10 years or more 47 , aside from the difficulties inherent in the analyses of secondary data, described in more detail in the subsection entitled "limitations". Meanwhile it must be emphasized that after the introduction of HAART and its universal access, it became especially important to monitor socioeconomic inequalities in reference to the incidence and mortality rates, not only for preventive actions, but, in particular, for actions of treatment/assistance, in order to guarantee equitable access to health services of desirable quality. 


\section{Mortality patterns}

More than 170,000 AIDS deaths had been recorded by the beginning of the present decade. The mortality curve from AIDS has followed, to a certain extent, the curve of case incidence 48 , reducing itself since the second half of the 1990s, initially showing an abrupt decline, followed by a less pronounced one.

AIDS mortality still is one of the principal causes of death in individuals from both sexes, especially among young adults, even though there has generally been a proportional decline in mortality as a result of a pronounced increase in the survival rate of both adult 49 , and child 21 patients, although this trend is heterogeneous among men and women and different geographic regions ${ }^{50}$. As of the beginning of the present decadeAIDSis nolonger the principal cause of death among young male adults, and there was a pronounced increase in the median age of death 51 . Meanwhile even though women always have had a lower death rate than men, a persistent growth in the AIDS mortality rates among women and in the Southern Region of the country has been observed 48 . Infectious and parasitic diseases and multiple infections have been the main diseases associated with AIDS deaths. In addition it has been observed that black men and women have a higher mortality rate from AIDS, with growth persisting until the beginning of the present decade ${ }^{51}$. Therefore men, and in general the population referred to as "white", have been the main beneficiaries of the reduction in AIDS mortality since the introduction of HAART 51, pointing to inequalities in the actual implementation of universal public health policies.

\section{Behavior patterns: face-to face with} the HIV infection

The behavior patterns and the interactions of relatively small specific segments of the population which show increased vulnerability and interconnectivity contribute substantially to the dynamics of the epidemic, resulting in it being disseminated into the general population 52,53 . Because of this, monitoring of risk behaviors of specific at-risk population segments has been the object of various surveys carried out locally, and countrywide, aiming to provide subsidies to be applied to the monitoring of preventive and control actions. Due to space limitations, only the principal findings of the population-based surveys will now be briefly reviewed.

Around $90 \%$ of the Brazilian population between the ages of 15-54 is sexually active, according to data from the National Survey of
Knowledge, Attitudes, and Practices 17. The age of sexual initiation is occurring earlier among the younger generations, beginning, actually, at around 15 years. This trend is in synchrony with findings from other countries, both developing 54 and developed 55

In correlation to this, the proportion of people that reported more than five casual partners in the year previous to being surveyed, has more than doubled among the younger generations, with multiple partners being reported more frequently by men than women 17 .

Meanwhile the use of a condom in the last sexual encounter is reported by just over a third of the Brazilian population, this being reported a lot more frequently among young people between 15 and 24 years, and among those who report sexual relations with casual partners 17 . What calls attention is the fact that around $90 \%$ of the Brazilian population spontaneously cite sexual relations as a form of HIV transmission 17, and the use of condoms as a way of preventing the risk of acquiring HIV 17, suggesting that knowledge and perception of risk do not necessarily translate into effective changes in behavior 56 .

In general, in the population as a whole 17 , and among young males (where the number of casual partners is higher, compared to other age groups and young women) between $17-20$ years 57 , the use of condoms with casual partners is much more frequent than with stable partners, and their utilization in the context of these relations has been steadily increasing over the years 57 . The adoption of safer behavior, principally on the part of the younger population, with an associated reduction in risk behavior 57 , has been observed consistently over the last decade, and seems to be reflected in the lower rates of AIDS in recent years, bearing in mind the time lag between HIV infection and AIDS reporting, as was mentioned earlier.

On the other hand, a sub-group of young Brazilian men continues practicing unprotected sex, with a significant number of partners and inconsistent use of condoms, and a higher proportion of homosexual relations (as a rule, unprotected) and with more frequently reporting signals and symptoms of sexually transmitted diseases (STDs) ${ }^{31}$. Among these youths that report having sexual relations with other men the use of condoms is infrequent, corresponding to half of the percentage reported among those that reported having sexual intercourse exclusively with women, even as casual partners, pointing out the persistence, or re-emergence, of high risk behavior among young male homosexuals, a phenomenon that has been observed in various countries 58 . 
Even though there is quite a high percentage of divulgation of correct information about HIV/AIDS, in some socioeconomic strata there have been observed some important differences regarding knowledge of the forms of transmission, and prevention, of HIV infection, with a lower proportion of correct answers given by individuals from lower social strata 17,57 , even among young people 57 , who are normally better informed.

In addition, those individuals with less education begin their sexual life much earlier, present higher rates of sexual activity, a greater number of casual partners, and less frequency of systematic use of condoms, factors that are linked to the acquisition of various STDs, including HIV 31. These factors point out the greater vulnerability of the poorer population, and explain, in part, the growth of the incidence of AIDS in these population segments $11,28,43$. There is no doubt, therefore, that universal initiatives of prevention are necessary to reinforce preventive action among these particularly vulnerable population segments.

\section{Estimates of HIV infection in Brazil}

The estimates on the number of HIV infected place Brazil among the countries with concentrated epidemics, with an overall HIV infection prevalence rate of $0.6 \%$ among individuals between 15-49 years old, and a prevalence rate of $0.8 \%$ and $0.4 \%$ among men and women, respectively 7 , rates that are similar to those estimated in 2000 59, signaling, therefore, a stabilization of the HIV epidemic. Among young males between the ages of 17-20, a precise estimate of HIV prevalence in 2002 was that of $0.09 \% 57$.

Even so it should be remembered that, in Brazil, men who have sex with other men, partners of individuals who test positive for HIV, IDU, and heterosexuals who engage in unprotected sex with multiple casual partners, be they commercial sex workers or not, are the most vulnerable to HIV infection, and there are no data available about these populations on the national, state, or local levels that can supply reliable or representative estimates about the prevalence of HIV or other STDs.

Although they are not representative of the universe of non-respondents, studies of commercial sex workers give estimates of infection rates between $6 \% 60$ and $11 \% 61$, this last findings being, unfortunately, chronologically out of phase.

A recent estimate points out a higher prevalence of HIV infection ( $0.56 \%)$, among young men 17-20 years old who reported relations with other men 57 . The report of homosexual relations was the principal variable that predicted the infection among young conscripts in the Brazilian army 31 . A higher prevalence rate of $0.21 \%$ among those youths that reported more than 10 sexual partners in their lives was also observed 57.

Among IDU studies carried out at the end of the 1990s, HIV point prevalence, in selected municipalities in the South and Southeast, was up to $52 \%$ among male IDU who had reported having sex with other men, documenting an overlapping or synergy of risks 62 . Here again are explicit synergies of risk and harm which demand, as previously stated, more focused and intensive interventions.

\section{Limitations of the present review and of the national databases}

Despite the urgent necessity of analyzing the nationwide databanks, it must be noted that these sources of data come with diverse orders of limitations. The following is an outline of a provisional taxonomy of the limitations made evident, starting with analyses of the principal national HIV/AIDS databanks: quality and completeness of information; delays/under-reporting of AIDS cases; and compatibility and comparability of successive revisions of the AIDS cases definitions.

\section{Quality and completeness of information}

The majority of the studies that describe the Brazilian epidemic are based on analyses of the AIDS cases databank (SINAN), at the national, state or municipal level.

A recent study 46 evaluated the consistency and completeness of variables considered essential for SINAN, from 1980 to 2003. The study found that the quality of case reporting had been improving over the years, with the worst performance relating to social and demographic variables, as was discussed earlier, for example, in the item referring to the variable "education". In general the completeness of the variables was more than $90 \%$, with notable exceptions including: "education" (76.3\%), "occupation" (70.4\%), "race/color" (51.1\%; variable included, starting in 2002), "sexual practices" (78.7\%; more than $90 \%$ among male respondents), "sexual partners" $45.3 \%$ to $58.2 \%$; depending on the nature of these partners, more, or less frequently), "injection drug use" (78.5\%), "AIDS case definition criteria for surveillance" (above 70\%) 46.

To the authors' knowledge, up to the present no external validation study has been published about AIDS case notifications in Brazil. 


\section{Delays and under-reporting of AIDS cases}

Another limitation of analyses of secondary data on reported AIDS cases refers to delays and under-reporting, which has been discussed in various studies $34,35,36,37$, and also makes trend analyses for the most recent period under study unreliable (if there are no delay correction strategies in place) 43 .

In 2004, the Brazilian Ministry of Health started to linkage related databanks, such as SISCEL and SIM, aiming to recuperating AIDS cases that till that time were not registered on SINAN 8,63,64. The procedure enabled recuperating cases that met the defining criteria for purposes of epidemiological surveillance 65 , especially for the years after to 2001, although gaps in inclusion of cases that had not been opportunely notified between 1999 and 2001, still persisted 8 .

Even though the recuperating of underreported cases has enabled development of analyses of more recent trends in the epidemic since 2002, another important limitation to this process has been the lack of fundamental data such as data on exposure categories of the recently added cases (see discussion referred to on Table 1), which can be obtained basically only through obligatory filling out of the AIDS Case Report Forms, a specific prerogative of services that are part of the country notification system 8 , and, because of this, impeding the analyses of more recent trends in the incidence of AIDS by category of exposure, fundamental to an adequate understanding of the recent dynamics of the epidemic.

\section{Compatibility and comparability of successive revisions of AIDS case definitions}

The successive revisions of the AIDS case definition criteria for the sake of epidemiological surveillance, in Brazil, had the objective to adjust the case reporting criteria to Brazilian health assistance reality (criteria Rio de Janeiro/Caracas ${ }^{65}$ ) and the employment of new technologies in the diagnostic and treatment of HIV/AIDS (criteria of the Centers for Disease Control and Prevention (CDC) adapted, i.e. the inclusion of T CD4+ lymphocyte counts under 350 cells/ $\mathrm{mm}^{3}{ }^{65}$ ). It is hoped that these definitions can be translated into a greater sensibility (without compromising specificity) in capturing cases to be reported, before they have to use ARV medication (indicated for HIV-seropositive individuals with a T CD4+ lymphocyte count of less than 200 cells $/ \mathrm{mm}^{3} 66$ ), postponing their inclusion as AIDS cases for purposes of epidemiological surveillance.
According to proposals from the World Health Organization (WHO), Brazil, upon the adoption of reviewed AIDS definition, will be including, among reported cases, those individuals with advanced HIV infections that are still not classified as AIDS cases, which are defined by a T CD4+ count of between 200 cells $/ \mathrm{mm}^{3}$ and 350 cells $/ \mathrm{mm}^{3} 67$.

Recent studies estimate that the incorporation of these latest criteria increased the sensitivity of AIDS case reports 68,69, that, therefore, are not yet using HAART, in accordance with the criteria established for treating patients with AIDS. On the other hand, the survival of patients is, to a certain extent, influenced by reporting criteria, given that if they can be diagnosed earlier they can benefit more fully from ARV therapy, than if they are diagnosed later, already showing clinical symptoms 70 .

It is important to point out that the different limitations presented are relative, and do not invalidate the findings presented here. The application of more sophisticated statistical techniques such as: the imputation of missing data 71 ; the utilization of discriminating analysis for the purpose of defining contrasting profiles of AIDS cases, and, afterwards, reclassification of missing data 11; and the utilization of Baysean estimators in procedures using back-calculation for incubation periods that violate the presupposition of stationarity 72 , to give examples of some of these alternatives.

\section{Final remarks}

In the context of a concentrated epidemic, with infection rates of less than $1 \%$ in the general population, there is a notable necessity for carrying out more detailed studies of the populations that are more vulnerable and under increased risk, such as MSM, IDU, commercial sex workers, and heterosexuals with behaviors who put them at risk of acquiring HIV infection, aside from having a better understanding of the underlying social inequality factors and abovementioned difficulties (for example, the spread of the epidemic into states of the Southern Region).

The findings reviewed in the present article consistently point to an epidemic concentrated in specific populations, overall stable, but with relevant gaps respecting the specific dynamics in some populations, due to the scarcity of available data.

The undeniable conquests in terms of a better control of the epidemic and management and treatment of people living with HIV/AIDS 73 should not be translated into premature celebra- 
tion and lenience in regard to the epidemic, be it on the part of the state, the activists, the NGOs, or the general public.

Among the innumerable challenges to be faced, the following ones stand out: the urgent need for studies to be made with representative samples of the most vulnerable populations, principally, MSM, IDU, and commercial sex workers, to minimally delineate risk factors, behaviors, and HIV infection trends; the strug- gle for equity in relation to all prevention and treatment methods; the progressive complexity and increased costs of treatment; the persistence of unacceptable rates of transmission in specific populations and among the poor; the emergence and eventual transmission of resistant strains of HIV-1.

Hopefully, the accumulated experience of errors and correct answers will serve as a guide and inspiration in the years to come.

\section{Resumo}

A epidemia de AIDS no Brasil vem experimentando na sua terceira década importantes mudanças. O presente artigo revê alguns achados centrais: a redução proporcional dos casos devido ao uso de drogas injetáveis, a estabilidade, em anos recentes, quanto aos casos novos referentes à categoria de exposição homo/ bissexual masculina e o incremento, relativo e absoluto, da transmissão heterossexual, ainda que estimativas das taxas de incidência sigam apontando as duas primeiras categorias como aquelas mais afetadas pela epidemia. Destaca-se, ainda, o persistente aumento das taxas de incidência entre as mulheres e sua estabilidade nas faixas etárias mais jovens, provavelmente, em decorrência de mudanças comportamentais (como o uso consistente de preservativos nas relações sexuais com parceiros eventuais entre os mais jovens e a redução dos casos devido ao uso de drogas injetáveis). $E$ notória a estabilidade da prevalência do HIV abaixo de $1 \%$ na população geral, o que define o Brasil como um dos países com uma epidemia concentrada. O artigo destaca ainda o crescimento da morbi-mortalidade por AIDS nas populações sócio-economicamente menos favorecidas e entre as mulheres, e a estabilidade da mortalidade por AIDS entre os homens.

Síndrome de Imunodeficiência Adquirida; Soroprevalência de HIV; Comportamento Sexual; Distribuição Temporal

\section{Contributors}

M. G. P. Fonseca participated in the conception, data analysis, writing, and final editing of the manuscript. F. I. Bastos collaborated on the conception, writing, and editing of the final manuscript. 


\section{References}

1. Joint United NationsProgramme on HIV/AIDS.2006 Report on the global AIDS epidemic. A UNAIDS 10th anniversary special edition. Executive summary. Geneva: Joint United Nations Programme on HIV/AIDS; 2006.

2. Palella Jr. FJ, Delaney KM, Moorman AC, Loveless MO, Fuhrer J, Satten GA, et al. Declining morbidity and mortality among patients with advanced human immunodeficiency virus infection. HIV Outpatient Study Investigators. N Engl J Med 1998; 338:853-60

3. Palella Jr. FJ, Baker RK, Moorman AC, Chmiel JS, Wood KC, Brooks JT, et al. Mortality in the highly active antiretroviral therapy era: changing causes of death and disease in the HIV outpatient study. J Acquir Immune Defic Syndr 2006; 43:27-34.

4. Cunningham WE, Hays RD, Duan N, Andersen R, Nakazono TT, Bozzette SA, et al. The effect of socioeconomic status on the survival of people receiving care for HIV infection in the United States. J Health Care Poor Underserved 2005; 16:655-76.

5. Fordyce EJ, Singh TP, Nash D, Gallagher B, Forlenza S. Survival rates in NYC in the era of combination ART. J Acquir Immune Defic Syndr 2002; 30:111-8.

6. Montaner JS, Hogg R, Wood E, Kerr T, Tyndall M, Levy AR, et al. The case for expanding access to highly active antiretroviral therapy to curb the growth of the HIV epidemic. Lancet 2006; 368:5316.

7. Szwarcwald CL, Souza-Júnior PRB. Estimativa da prevalência de HIV na população brasileira de 15 a 49 anos, 2004. Boletim Epidemiológico AIDST 2006; Ano III, no. 1. p. 11-5.

8. Ministério da Saúde. Boletim Epidemiológico AIDST 2006; Ano III, no. 01.

9. Bastos FI, Barcellos C. Geografia social da AIDS no Brasil. Rev Saúde Pública 1995; 29:52-62.

10. Dourado I, Veras MASM, Barreira D, Brito AM. Tendências da epidemia de AIDS no Brasil após a terapia anti-retroviral. Rev Saúde Pública 2006; 40 Suppl:9-17.

11. Fonseca MG, Bastos FI, Derrico M, Andrade CLT, Travassos C, Szwarcwald CL. AIDS e grau de escolaridade no Brasil: evolução temporal de 1986 a 1996. Cad Saúde Pública 2000; 16 Suppl 1:S77-87.

12. Hacker MA, Leite IC, Renton A, Torres TG, Gracie $\mathrm{R}$, Bastos FI. Reconstructing the AIDS epidemic among injection drug users in Brazil. Cad Saúde Pública 2006; 22:751-60.

13. Wanderley DMV, Gonzales TT, Pereira MSCA, Nascimento RD, Moraes-Souza H. Controle da hemoterapia e da doença de Chagas transfusional: 1988 e 1990. Rev Saúde Pública 1993; 27:430-5.

14. Ministério da Saúde. Recomendações para profilaxia da transmissão materno-infantil do HIV e terapia anti-retroviral. http://www.aids.gov.br/data/Pages/LUMISFB7D5720PTBRIE.htm (accessed on $20 / \mathrm{Dec} / 2006$ ).

15. Szwarcwald CL, Bastos FI, Esteves MAP, Andrade CLT. A disseminação da epidemia da AIDS no Brasil, no período de 1987-1996: uma análise espacial. Cad Saúde Pública 2000; 16 Suppl 1:S7-19.
16. Fonseca MGP, Castilho EA. Os casos de AIDS entre os usuários de drogas injetáveis. Brasil, 1980-1997. Boletim Epidemiológico AIDS 1997; Ano X, no. 3. p. 6-14.

17. Szwarcwald CL, Barbosa-Júnior A, Pascom AR, Souza-Júnior PR. Knowledge, practices and behaviours related to HIV transmission among the Brazilian population in the $15-54$ years age group, 2004. AIDS 2005; 19 Suppl 4:S51-8.

18. Catania JA, Osmond D, Stall RD, Pollack L, Paul JP, Blower S, et al. The continuing HIV epidemic among men who have sex with men. Am J Public Health 2001; 91:907-14.

19. Mofenson LM. Reducing the risk of perinatal HIV1 transmission with zidovudine: results and implications of AIDS Clinical Trials Group Protocol 076. Acta Paediatr Suppl 1997; 421:89-96.

20. Mussi-Pinhata MM, Kato CM, Duarte G, Paschoini MC, Bettiol H, Quintana SM. Factors associated with vertical HIV transmission during two different time periods: the impact of zidovudine use on clinical practice at a Brazilian reference centre. Int J STD AIDS 2003; 14:818-25.

21. Matida LH, Marcopito LF, Succi RC, Marques HH, Della Negra M, Grangeiro A, et al. Improving survival among Brazilian children with perinatally-acquired AIDS. Braz J Infect Dis 2004; 8:419-23.

22. Brito AM, Sousa JL, Luna CF, Dourado I. Tendência da transmissão vertical de AIDS após terapia antiretroviral no Brasil. Rev Saúde Pública 2006; 40:1822.

23. Vasconcelos ALR, Hamann EM. Why does Brazil still report high rates of vertical HIV transmission? An evaluation of health care quality to HIV-infected pregnant women and their children. Rev Bras Saúde Matern Infant 2005; 5:483-92.

24. Souza-Júnior PR, Szwarcwald CL, Barbosa Junior A, Carvalho MF, Castilho EA. Infecção pelo HIV durante a gestação: Estudo-Sentinela Parturiente, Brasil, 2002. Rev Saúde Pública 2004; 38:764-72.

25. Ministério da Saúde. Relatório: primeiros resultados do Estudo-Sentinela Parturiente. http://www. aids.gov.br/final/biblioteca/relatorios_07_2005/ relatorio_2004_sentinela_parturiente.pdf (accessed on 20/Dec/2006).

26. Turchi MD, Duarte LS, Martelli CMT. Mother-tochild transmission of HIV: risk factors and missed opportunities for prevention among pregnant women attending health services in Goiânia, Goiás State, Brazil. Cad Saúde Pública 2007; 23 Suppl 3: S390-401.

27. Szwarcwald CL, Bastos FI, Barcellos C, Esteves MAP, Castilho EA. Dinâmica da epidemia de AIDS no Município do Rio de Janeiro, no período de 1988-1996: uma aplicação de análise estatística espaço-temporal. Cad Saúde Pública 2001; 17:112340.

28. Fonseca MGP, Travassos C, Bastos FI, Silva NV, Szwarcwald CL. Distribuição social da AIDS no Brasil, segundo participação no mercado de trabalho, ocupação e status sócio-econômico dos casos de 1987 a 1998. Cad Saúde Pública 2003; 19:135163. 
29. Ministério da Saúde. Dados de AIDS no Brasil (banco de dados). http://www.aids.gov.br/final/dados/ dados_aids.asp (accessed on 04/Dec/2006).

30. Bastos FI, Bongertz V, Teixeira SL, Morgado MG, Hacker MA. Is human immunodeficiency virus/ acquired immunodeficiency syndrome decreasing among Brazilian injection drug users? Recent findings and how to interpret them. Mem Inst Oswaldo Cruz 2005; 100:91-6.

31. Ministério da Saúde. Relatório: estudo comportamental com conscritos 2002. http://www.aids.gov. br/data/Pages/LUMIS72418C70PTBRIE.htm (accessed on 20/Dec/2006).

32. Bastos FI, Kerrigan D, Malta M, Carneiro-daCunha C, Strathdee SA. Treatment for HIV/AIDS in Brazil: strengths, challenges, and opportunities for operations research. AIDScience 2001; 1. http:// aidscience.com/Articles/aidscience012.asp (accessed on 20/Dec/2006).

33. Porco TC, Martin JN, Page-Shafer KA, Cheng A, Charlebois E, Grant RM, Osmond DH. Decline in HIV infectivity following the introduction of highly active antiretroviral therapy. AIDS 2004; 18:81-8.

34. Barbosa MTS, Struchiner CJ. Estimativas do número de casos de AIDS no Brasil, corrigidas pelo atraso de notificação. Rev Bras Epidemiol 1998; 1:234-44.

35. Ferreira VMB, Portela MC. Avaliação da subnotificação de casos de AIDS no Município do Rio de Janeiro com base em dados do sistema de informações hospitalares do Sistema Único de Saúde. Cad Saúde Pública 1999; 15:317-24.

36. Lemos KRV, Valente JG. A declaração de óbito como indicador de sub-registro de casos de AIDS. Cad Saúde Pública 2001; 17:617-26.

37. Oliveira MTC, Barreira D, Santos LCO, Latorre MRDO. A subnotificação de casos de AIDS em municípios brasileiros selecionados: uma aplicação do método de captura-recaptura. Boletim Epidemiológico AIDST 2004; Ano XVIII, no. 1. p. 7-11.

38. Chandeying V. Epidemiology of HIV and sexually transmitted infections in Thailand. Sex Health 2004; 1:209-16.

39. Williams JR, Foss AM, Vickerman P, Watts C, Ramesh BM, Reza-Paul S, et al. What is the achievable effectiveness of the India AIDS Initiative intervention among female sex workers under target coverage? Model projections from southern India. Sex Transm Infect 2006; 82:372-80.

40. Bonolo PF, Cesar CC, Acurcio FA, Ceccato MG, Padua CA, Alvares J, et al. Non-adherence among patients initiating antiretroviral therapy: a challenge for health professionals in Brazil. AIDS 2005; 19 Suppl 4:S5-13.

41. Boily MC, Godin G, Hogben M, Sherr L, Bastos FI. The impact of the transmission dynamics of the HIV/AIDS epidemic on sexual behaviour: a new hypothesis to explain recent increases in risk taking-behaviour among men who have sex with men. Med Hypotheses 2005; 65:215-26.

42. Grangeiro A. O perfil socioeconômico da AIDS no Brasil. In: Parker R, Bastos C, Galvão J, Pedrosa JS, organizadores. A AIDS no Brasil. Rio de Janeiro; Associação Brasileira Interdisciplinar de AIDS/ Universidade do Estado do Rio de Janeiro/Editora Relume-Dumará; 1994. p. 91-125.
43. Fonseca MGP, Szwarcwald CL, Bastos FI. Análise sociodemográfica da epidemia de AIDS no Brasil, 1989-1997. Rev Saúde Pública 2002; 36:678-85.

44. Barbosa LM, Sawyer DO. AIDS: a vulnerabilidade social e a evolução da epidemia nos municípios das regiões Nordeste e Sudeste do Brasil. Rev Bras Estud Popul 2003; 20:241-57.

45. Klovdahl AS. Social networks and the spread of infectious diseases: the AIDS example. Soc Sci Med 1985; 21:1203-16.

46. Glatt R. Análise da qualidade da base de dados de AIDS do Sistema de Informação de Agravos de Notificação (SINAN) [Masters Thesis]. Rio de Janeiro: Fundação Oswaldo Cruz; 2005.

47. Porter K, Johnson AM, Phillips AN, Darbyshire JH. The practical significance of potential biases in estimates of the AIDS incubation period distribution in the UK register of HIV seroconverters. AIDS 1999; 13:1943-51.

48. Hacker MA, Petersen ML, Enriquez M, Bastos FI. Highly active antiretroviral therapy in Brazil: the challenge of universal access in a context of social inequality. Rev Panam Salud Pública 2004; 16:7883.

49. Marins JR, Jamal LF, Chen SY, Barros MB, Hudes ES, Barbosa AA, et al. Dramatic improvement in survival among adult Brazilian AIDS patients. AIDS 2003; 17:1675-82.

50. Fonseca MG, Barreira D. A evolução da mortalidade por AIDS no país, segundo sua distribuição geográfica. Boletim Epidemiológico AIDS 2000, ano XIII, n. 3. http://www.aids.gov.br/data/Pages/ LUMIS624DE984PTBRIE.htm (accessed on 23/ Oct/2006).

51. Fonseca MGP, Lucena FFA, Sousa A, Bastos FI. AIDS mortality, "race color", and social inequality in a context of universal access to highly active antiretroviral therapy (HAART) in Brazil, 1999-2004. Cad Saúde Pública 2007; 23 Suppl 3:S445-55.

52. Boily MC, Poulin R, Masse B. Some methodological issues in the study of sexual networks: from model to data to model. Sex Transm Dis 2000; 27:558-71.

53. Périssé ARS, Nery JAC. The relevance of social network analysis on the epidemiology and prevention of sexually transmitted diseases. Cad Saúde Pública 2007; 23 Suppl 3:S361-9.

54. Liu A, Kilmarx P, Jenkins RA, Manopaiboon C, Mock PA, Jeeyapunt S, et al. Sexual initiation, substance use, and sexual behavior and knowledge among vocational students in northern Thailand. Int Fam Plan Perspect 2006; 32:126-35.

55. Ompad DC, Strathdee SA, Celentano DD, Latkin C, Poduska JM, Kellam SG, et al. Predictors of early initiation of vaginal and oral sex among urban young adults in Baltimore, Maryland. Arch Sex Behav 2006; 35:53-65.

56. Souza CT, Bastos FI, Lowndes CM, Szwarcwald CL, Santos EM, Castilho EA, et al. Perception of vulnerability to HIV infection in a cohort of homosexual/bisexual men in Rio de Janeiro, Brazil. Oswaldo Cruz Foundation STD/HIV Prevention Group. AIDS Care 1999; 11:567-79.

57. Szwarcwald CL, Carvalho MF, Barbosa Junior A, Barreira D, Speranza FA, Castilho EA. Temporal trends of HIV-related risk behavior among Brazilian military conscripts, 1997-2002. Clinics 2005; 60:367-74 
58. Piaseczna MA, Craib KJ, Li K, Chan K, Weber AE, Strathdee SA, et al. Longitudinal patterns of sexual behavior and condom use in a cohort of HIV-negative gay and bisexual men in Vancouver, British Columbia, Canada, 1995-2000. J Acquir Immune Defic Syndr 2001; 28:187-93.

59. Szwarcwald CL, Carvalho MF. Estimativa do número de indivíduos de 15 a 49 anos infectados pelo HIV, Brasil, 2000. Boletim Epidemiológico AIDS 2001; ano XIV, n. 1. http://www.aids.gov.br/final/ biblioteca/bol_set_2001/artigo.htm (accessed on 20/Dec/2006).

60. Guimarães K, Godoi AMM, Mercán-Hamann E, Andrade JMJ. Avaliação da efetividade das ações de prevenção dirigidas às profissionais do sexo, em três regiões brasileiras. 1a Ed. Brasília: Programa Nacional de DST e AIDS, Secretaria de Vigilância em Saúde, Ministério da Saúde; 2004.

61. Lurie P, Fernandes ME, Hughes V, Arevalo EI, Hudes ES, Reingold A, et al. Socioeconomic status and risk of HIV-1, syphilis and hepatitis B infection among sex workers in Sao Paulo State, Brazil. Instituto Adolfo Lutz Study Group. AIDS 1995; Suppl 1: S31-7.

62. Ferreira AD, Caiaffa WT, Bastos FI, Mingoti SA; Projeto AjUDE-Brasil II. Injecting drug users who are (un)aware of their HIV serostatus: findings from the multi-center study AjUDE-Brasil II. Cad Saúde Pública 2006; 22:815-26.

63. Ministério da Saúde. Boletim Epidemiológico AIDST 2004; Ano XVIII, no. 1.

64. Lucena FFA, Fonseca MGP, Sousa AIA, Coeli CM. O relacionamento de bancos de dados na implementação da vigilância de AIDS. Relacionamento de dados e vigilância da AIDS. Cad Saúde Coletiva 2006; XIV:305-12.
65. Ministério da Saúde. Critérios de definição de casos de AIDS em adultos e crianças. Brasília: Ministério da Saúde; 2004.

66. Ministério da Saúde. Recomendações para terapia anti-retroviral em adultos e adolescentes infectados pelo HIV. Brasília: Ministério da Saúde; 2006.

67. World Health Organization. Interim WHO clinical staging of HIV/AIDS and HIV/AIDS case definitions for surveillance. African Region. Geneva: World Health Organization; 2005.

68. Kilsztajn S. Critérios de notificação e tendência temporal da epidemia de AIDS no Estado de São Paulo, 1980-98. Rev Bras Epidemiol 2001; 4:96-104.

69. Miranda PSC, Andrés M, Caylá JA, Galdós-Tangüis H, García de Olalla P. Validation of four AIDS-case definitions in HIV-infected intravenous drug users in Barcelona, Spain. Rev Bras Epidemiol 1998; 1:170-6.

70. Campos DP, Ribeiro SR, Grinsztejn B, Veloso VG, Valente JG, Bastos FI, et al. Survival of AIDS patients using two case definitions, Rio de Janeiro, Brazil, 1986-2003. AIDS 2005; 19 Suppl 4:S22-6.

71. Barnard J, Meng XL. Applications of multiple imputations in medical studies: from AIDS to NHANES. Stat Methods Med Res 1999; 8:17-36.

72. Sweeting MJ, De Angelis D, Aalen OO. Bayesian back-calculation using a multi-state model with application to HIV. Stat Med 2005; 24:3991-4007.

73. Hacker MA, Kaida A, Hogg RS, Bastos FI. The first ten years: achievements and challenges of the Brazilian program of universal access to HIV/AIDS comprehensive management and care, 1996-2006. Cad Saúde Pública 2007; 23 Suppl 3:S345-59.

Submitted on 03/Jan/2007

Final version resubmitted on 18/Apr/2007

Approved on 19/Apr/2007 